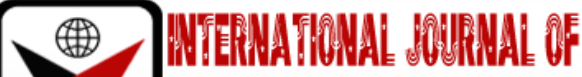

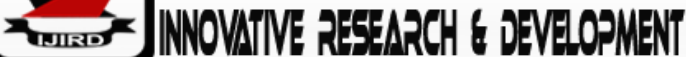

ISSN 2278-0211 (Online)

\section{Youth Involvement in Organic Production of Selected Arable Crops: Panacea to Increased Food Production in the Era of COVID-19 Pandemic in Osun State, Nigeria}

Olajide Julius Filusi
Graduate Student, Department of Agricultural Extension and Rural Development,
Obafemi Awolowo University Ile-Ife, Nigeria
Adejumoke Bosede Ale
Chief Lecturer, Department of Agricultural Science
Adeyemi College of Education Ondo, Nigeria
Oluwafolakemi Ibukun Ogungbemi
Lecturer, Department of Agricultural Science
Adeyemi College of Education Ondo, Nigeria

\section{Abstract:}

The study assessed the youth involvement in organic production of selected arable crops in Osun State, Nigeria. Purposive sampling technique was used to select three agro-ecological zones; Iwo, Osogbo and Ife/Ijesa. A random sampling procedure was used to select two communities from two local government areas in each agro-ecological zone. Finally, snowball sampling procedure was used to select 50 youth from each community making a total of 600 respondents for the study. A well-structured interview schedule was used to collect quantitative data. The data collected were summarised with percentages, means and standard deviation while chi-square and correlation analysis were used to draw inferences.

Resultsshow that there was significant association between the level of involvement and sex $\left(\chi^{2}=22.412, P \leq 0.01\right)$, marital status $\left(\chi^{2}=18.900, P \leq 0.01\right)$ and cosmopoliteness $\left(\chi^{2}=41.214, P \leq 0.01\right)$ of the respondents. Also, the results of Correlation show that household size $(r=-0.209, p \leq 0.05)$ and years of formal education $(r=-0.200, p \leq 0.05)$ had significant but negative relationship with the involvement while years of farming experience $(r=0.263)$ had positive and significant relationship with the involvement of youth at $p \leq 0.01$.

The study concluded that the youth had a moderate (49.1\%) level of involvement in organic production of selected arable crops in the study area.

Keywords: Involvement, Youth, COVID-19, Organic production

\section{Introduction}

Natural cultivating first came into utilization in the United States during the 1940s, in any case, natural harvest creation didn't start to truly create as an industry until the 1970s (AGRA, 2015). As per Food and Agricultural Organization (FAO, 2018) natural horticulture creation is a comprehensive creation the board framework which advances and improves agro-environment wellbeing, including biodiversity, organic cycles, and soil organic movement. It underscores the utilization of the board rehearses in inclination to the utilization of off-ranch inputs, considering that local conditions require privately adjusted frameworks. This is cultivated by utilizing, where conceivable, agronomic, organic, and mechanical strategies, rather than utilizing manufactured materials, to satisfy a particular capacity inside the framework. Natural agrarian creation is a creation framework that supports the wellbeing of soils, environments and individuals. It depends on biological cycles, biodiversity and cycles adjusted to neighborhood conditions, as opposed to the utilization of contributions with antagonistic impacts, it additionally joins custom, development and science to profit the common climate and advance reasonable connections and a decent personal satisfaction for all included. As indicated by Olaito (2014), Nigeria has more than 170 million individuals making it the most crowded country in Africa. The country's financial pillar before the oil blast was agribusiness. The act of natural horticulture in a coordinated way is still new to the country, with under ten years of utilization. In 2007, Nigeria had 3,154 ha under natural agribusiness of which 59 ha were completely changed over and overseen by a couple of ranchers and Non-Governmental Organization (NGO), with little government association. Notwithstanding, it was accounted for that in 2010, land under natural creation expanded to 11,979 ha with 517 makers.

In Nigeria, natural cultivating has been polished from that point forward, even some country ranchers have never changed their type of cultivating, they never utilize regular that is broad now, not just due to significant expense of 
contributions because of boundary conclusion during COVID-19 pandemic lockdown yet additionally in view of their degree of destitution (Lamidi, 2015). As per Arndt, Chuku, Adeniran, Morakinyo, Victor, George and Chukwuka (2018), preceding the flare-up of COVID-19 Pandemic across the globe, horticultural advancements do observer bunches of difficulties throughout the long term. Nigeria has managed low yield per hectare because of deficient soil richness, deficiencies in the stock of contributions just as lacking water system and reaping frameworks, which thwarts efficiency and yield rate, which natural cultivating will in general address.

\section{Material and Method}

The study was conducted in Osun state, which is one of the 36 states in Nigeria. The state was created out of Oyo state, on the $27^{\text {th }}$ of August, 1991 with its capital in Osogbo. It covers an area of approximately 9,251 square kilometres and it is bound in the north by Kwara State, in the east partly by Ekiti State and partly by Ondo State, in the south by Ogun State and in the west by Oyo State. It lies in the coordinates of $7^{\circ} 30^{\prime} \mathrm{N}$ and $4^{\circ} 30^{\prime} \mathrm{E}$. National population commission (NPC) (2006) analytically reported the population of Osun State as 3,423,535 with 30 Local Government Area (LGAs) and one area office. Osun is the home to several of Nigeria's pre-eminent institution of higher learning. The university is located in the ancient town Kara of Ile-Ife, an important early centre of political and religious development for Yoruba culture. Other important cities and towns include the ancient kingdom capital of Oke-IlaOrangun, Ijebu-Jesa, Ede, Iwo, Ejigbo, Modakeke, Ibokun, Ifetedo, Esa-Oke and Ilesa among others. The indigenes of the state belong to the Yoruba ethnic group and are composed of the Ife, IjesaIgbomina and Oyo. Multistage sampling procedure was used for the sample selection. At the first stage, Osun state was purposefully selected for the study because of mass participation of youth in agriculture and an history of the youth involvement in the past agricultural transformation agenda. At the second stage, purposive sampling technique was used in selecting the three agro-ecological zones; Iwo, Osogbo and Ife/Ijesa because of presence of large number of agricultural oriented youth. At the third stage, random sampling technique was used to select two communities from two Local Government Areas in each agro-ecological zone. At the final stage, snowball sampling technique was used to select 50 youth from each community, making a total of 600 respondents in the study area. A well-structured and validated interview schedule was used to collect quantitative data which were summarized with percentages, means and standard deviation while chi-square and correlation were used to draw inferences.

\section{Results and Discussion}

\subsection{Socio-Economic Characteristics of Youth}

Mean age of the respondents was $35 \pm 8$ years, more than half $(53.7 \%)$ of the respondents were female while 46.3 percent of the respondents were male, the mean years of formal education was $13.08 \pm 3.21$ years, 53.7 percent of the respondents were practicing Islamic religion while 46.3 percent were adherents to Christian religion, majority of the respondents (88.9\%) were married, 8.3 percent were single, while very few $(2.9 \%)$ were divorced, The mean household size was $5.09 \pm 1.49$ years, The mean monthly income earned by the respondents was $\$ 35,000.00 \pm \$ 11,300$, The mean years of farming experience of the respondents was $10.19 \pm 4.56$ years.

\begin{tabular}{|c|c|c|c|c|}
\hline Variables & Frequency & Percentage & Mean & Standard Deviation \\
\hline Age (years) & & & & \\
\hline $20-30$ & 211 & 35.2 & 34.54 & 7.81 \\
\hline $31-40$ & 266 & 44.4 & & \\
\hline $41-50$ & 106 & 17.6 & & \\
\hline Above 50 & 17 & 2.8 & & \\
\hline Sex & 278 & 46.3 & & \\
\hline Male & 322 & 53.7 & & \\
\hline Female & & & & \\
\hline Years of formal education & 194 & 32.4 & 13.08 & \\
\hline $5-10$ & 217 & 36.1 & & \\
\hline $11-15$ & 189 & 31.5 & & \\
\hline $16-20$ & & & & \\
\hline Religion & 278 & 46.3 & & \\
\hline Christianity & 322 & 53.7 & & \\
\hline Islam & & & & \\
\hline Marital status & 50 & 8.3 & & \\
\hline Single & 533 & 88.9 & & \\
\hline Married & 17 & 2.9 & & \\
\hline Divorced & & & & \\
\hline Household size & 111 & 18.5 & 5.09 & \\
\hline 1-3 & 356 & 59.3 & & \\
\hline 4-6 & 133 & 22.2 & & \\
\hline Above 6 & 239 & 39.8 & 35,000 & \\
\hline Average monthly income (N) & & & & \\
\hline 20,000-30,000 & 239,300 \\
\hline
\end{tabular}




\begin{tabular}{|c|c|c|c|c|}
\hline Variables & Frequency & Percentage & Mean & Standard Deviation \\
\hline $31,000-40,000$ & 155 & 25.9 & & \\
\hline $41,000-50,000$ & 139 & 23.1 & & \\
\hline $51,000-60,000$ & 67 & 11.1 & & \\
\hline Year of farming experience & & & & \\
\hline $1-5$ & 122 & 20.4 & 10.19 & \\
\hline $6-10$ & 250 & 41.7 & & \\
\hline $11-15$ & 184 & 30.6 & & \\
\hline $16-20$ & 28 & 4.6 & & \\
\hline$>20$ & 16 & 2.8 & & \\
\hline
\end{tabular}

Table 1: Distribution of Respondents by Their, Age, Sex, Years of Formal Education,

Religion, Marital Status, Household Size, Monthly Income and Farming Experience

$$
N=600
$$

Source: Field Survey, 2021

\subsection{Selected Arable Crops for Organic farming}

Results in Table 2 show that all the respondents (100\%) indicated maize, 80.6 percent indicated cassava, 65.7 percent indicated potato, 65.7 percent indicated soybean, 63.9 percent indicated rice, 45.4 percent indicated cowpea, 25.9 percent indicated cotton and very few (12\%) of the respondents indicated barley as the type of arable crops they use organic farming for. From the findings, it was discovered that maize and cassava were the main types of arable crops the respondents were mostly involved in its organic production while cotton and barley ranked the least of all the arable crops the respondents were involved in its organic production. This may be as a result of the fact that the study area belonged to a rainforest agricultural zone that support the growth of arable crops like maize and cassava.

\begin{tabular}{|c|c|c|}
\hline Crops* & Frequency & Percentage \\
\hline Maize & 600 & 100.0 \\
\hline Cassava & 484 & 80.6 \\
\hline Potato & 394 & 65.7 \\
\hline Soybean & 394 & 65.7 \\
\hline Rice & 383 & 63.9 \\
\hline Cowpea & 272 & 45.4 \\
\hline Cotton & 155 & 25.9 \\
\hline Barley & 72 & 12.0 \\
\hline
\end{tabular}

Table 2: Distribution of Respondents Based on Selected

Arable Crops for Organic Farming

$$
N=600
$$

Source: Field Survey, 2021

*Multiple Responses

\subsection{Youth Involvement in Activities of Organic Agricultural Production of Arable Crops}

Results in Table 3 show that crop rotation (mean $=2.47$ ),ranked the highest of all the activities involved in by the respondents in organic production of arable crops followed by mulching (mean $=2.40$ ), use of green manure (mean $=$ 2.17 ), planting of cover crops (mean $=2.06)$, use of biological control (mean $=2.03)$, manual weeding (mean $=2.03$ ), reduction of external and off-farm inputs (mean $=1.99)$, prevention of bush burning (mean $=1.96$ ), use of animal dung's (mean $=1.88)$, reduction of pollutants from the soil (mean $=1.81)$, creation of compost $($ mean $=1.81)$, polyculture practices $($ mean $=1.81)$, monoculture practices $($ mean $=1.79)$, rotational grazing $($ mean $=1.60)$ while elimination of synthetic pesticides and fertilizer (mean $=1.49$ ) ranked the least among the activities involved in by the respondents. However, the grand mean score for the involvement of activities in organic production of arable crops was 1.95 . This implies that respondents were moderately involved in all the activities.

\begin{tabular}{|c|c|c|c|c|c|c|}
\hline $\begin{array}{c}\text { Organic Production of } \\
\text { Arable Crop Variables }\end{array}$ & $\begin{array}{c}\text { NI } \\
\text { Freq(\%) }\end{array}$ & $\begin{array}{c}\text { SI } \\
\text { Freq(\%) }\end{array}$ & $\begin{array}{c}\text { MI } \\
\text { Freq(\%) }\end{array}$ & $\begin{array}{c}\text { FI } \\
\text { Freq(\%) }\end{array}$ & $\begin{array}{c}\text { Mean } \\
\text { Score }\end{array}$ & Rank \\
\hline Crop rotation & $61(10.2)$ & $39(6.5)$ & $56(9.3)$ & $444(74.1)$ & 2.47 & $1^{\text {st }}$ \\
\hline Mulching & - & $122(20.4)$ & $116(19.4)$ & $362(60.2)$ & 2.40 & $2^{\text {nd }}$ \\
\hline Use of green manure & $116(19.4)$ & $6(0.9)$ & $139(23.1)$ & $339(56.5)$ & 2.17 & $3^{\text {rd }}$ \\
\hline Planting of cover crops & $22(3.7)$ & $217(36.1)$ & $66(11.1)$ & $295(49.1)$ & 2.06 & $3^{\text {rd }}$ \\
\hline Use of biological control & $6(0.9)$ & $211(35.2)$ & $144(24.1)$ & $239(39.8)$ & 2.03 & $5^{\text {th }}$ \\
\hline $\begin{array}{c}\text { Manual weeding } \\
\text { Reduction of external } \\
\text { and off-farm inputs }\end{array}$ & $106(17.6)$ & $11(1.9)$ & $244(40.7)$ & $239(39.8)$ & 2.03 & $6^{\text {th }}$ \\
\hline $\begin{array}{c}\text { Prevention of bush } \\
\text { burning }\end{array}$ & $39(6.5)$ & $111(18.5)$ & $283(47.2)$ & $167(27.8)$ & 1.96 & $7^{\text {th }}$ \\
\hline
\end{tabular}




\begin{tabular}{|c|c|c|c|c|c|c|}
\hline $\begin{array}{c}\text { Organic Production of } \\
\text { Arable Crop Variables }\end{array}$ & $\begin{array}{c}\text { NI } \\
\text { Freq(\%) }\end{array}$ & $\begin{array}{c}\text { SI } \\
\text { Freq(\%) }\end{array}$ & $\begin{array}{c}\text { MI } \\
\text { Freq(\%) }\end{array}$ & $\begin{array}{c}\text { FI } \\
\text { Freq(\%) }\end{array}$ & $\begin{array}{c}\text { Mean } \\
\text { Score }\end{array}$ & Rank \\
\hline Use of animal dungs & $62(10.2)$ & $194(32.4)$ & $100(16.7)$ & $244(40.7)$ & 1.88 & $9^{\text {th }}$ \\
\hline $\begin{array}{c}\text { Reduction of pollutants } \\
\text { from the soil }\end{array}$ & $116(19.4)$ & $100(16.7)$ & $167(27.8)$ & $217(36.1)$ & 1.81 & $10^{\text {th }}$ \\
\hline Creation of compost & $122(20.4)$ & $117(19.4)$ & $117(19.4)$ & $244(40.7)$ & 1.81 & $10^{\text {th }}$ \\
\hline Polyculture practices & $89(14.8)$ & $150(25.0)$ & $150(25.0)$ & $211(35.2)$ & 1.81 & $10^{\text {th }}$ \\
\hline Monoculture practices & $111(18.5)$ & $105(17.6)$ & $184(30.6)$ & $200(33.3)$ & 1.79 & $13^{\text {th }}$ \\
\hline Rotational grazing & $228(38.0)$ & - & $155(25.9)$ & $217(36.1)$ & 1.60 & $14^{\text {th }}$ \\
\hline $\begin{array}{c}\text { Elimination of synthetic } \\
\text { pesticides and fertilizer }\end{array}$ & $194(32.4)$ & $50(8.3)$ & $222(37.0)$ & $134(22.2)$ & 1.49 & $15^{\text {th }}$ \\
\hline
\end{tabular}

Table 3: Youth Involvement in Activities of Organic Agricultural Production of

Selected Arable Crops Grand Mean $=1.95$

$$
N=600
$$

Source: Field Survey, 2021

\subsection{Level of Involvement of Youth in Organic Production of Selected Arable Crops}

Results from Figure 1 show the overall level of involvement of the youths in organic production of arable crops in the study area. The results show that 49.1 percent of the respondents were moderately involved in organic production of selected arable crops, 41.7 percent were highly involved and 9.3 percent had low level of involvement in organic production of arable crops in the study area. This implies that at least 90.8 percent of the respondents were either moderately or highly involved in organic production of arable crops. The finding indicates that the youths had moderate level of involvement in organic production in selected arable crops.

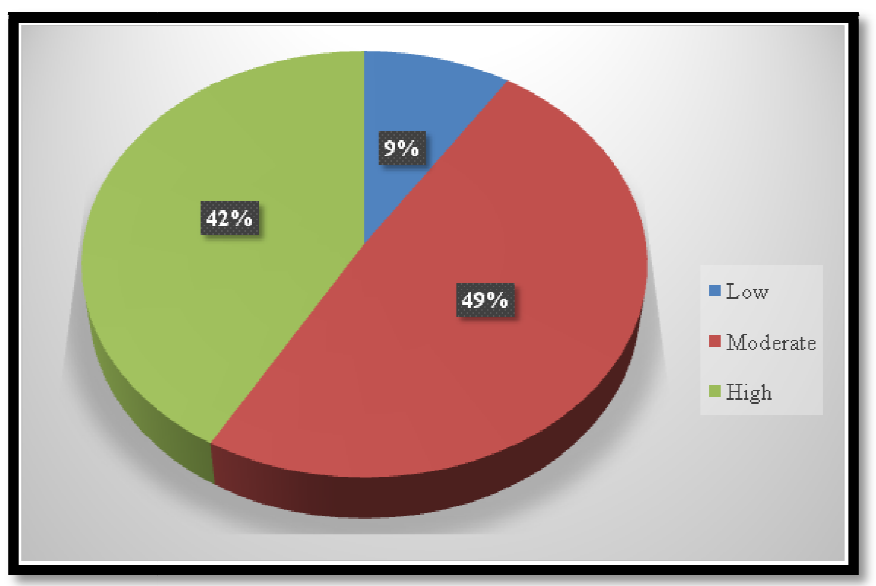

Figure 1: Pie Chart Showing the Level of Involvement in Organic Production of Some Selected Arable Crops Source: Field Survey, 2021

\subsection{The Perceptions of Youth towards Organic Production of Arable Crops}

Results in Table 4 show the perceptions of respondents towards organic production in arable crops. It revealed that the statement, it is the best way to increase crop productivity during COVID-19 lockdown $($ mean $=2.61)$ ranked the highest of all the statement followed by it Involves more working power than conventional farming (mean $=2.05$ ), it results to low production (mean $=1.94)$, suitable for small and subsistence farms (mean $=1.89$ ), it needs high financial resources for inputs (mean $=1.85)$, it can assure the need of agricultural procedures at national level $($ mean $=1.67)$, it uses natural fertilizers and pesticides (mean $=1.61)$, while it protects the natural environment $($ mean $=1.56)$ and it uses chemical fertilizers and pesticides (mean $=1.56$ ) ranked the least of all the perceptions of the respondents towards organic production of arable crops in the study area. The findings show that the grand perceptional mean is 1.86 which shows that the majority of the respondents have positive perception towards organic production of selected arable crops in the study area. 


\begin{tabular}{|c|c|c|c|c|c|c|}
\hline Variables & $\begin{array}{c}\text { SD } \\
\text { Freq(\%) }\end{array}$ & $\begin{array}{c}\text { D } \\
\text { Freq (\%) }\end{array}$ & $\begin{array}{c}\text { A } \\
\text { Freq (\%) }\end{array}$ & $\begin{array}{c}\text { SA } \\
\text { Freq (\%) }\end{array}$ & Mean & Rank \\
\hline $\begin{array}{c}\text { It is the best way to increase } \\
\text { crop productivity during COVID- } \\
\text { 19 lockdown }\end{array}$ & $56(9.3)$ & - & $67(11.1)$ & $477(79.6)$ & 2.61 & $1^{\text {st }}$ \\
\hline $\begin{array}{c}\text { It Involves more working power } \\
\text { than conventional farming }\end{array}$ & $78(13.0)$ & $78(13.0)$ & $184(30.6)$ & $261(43.5)$ & 2.05 & $2^{\text {nd }}$ \\
\hline Results to low production & $139(23.1)$ & $45(7.4)$ & $133(22.2)$ & $283(47.2)$ & 1.94 & $3^{\text {rd }}$ \\
\hline $\begin{array}{c}\text { Suitable for small and } \\
\text { subsistence farms }\end{array}$ & $34(5.6)$ & $150(25.0)$ & $266(44.4)$ & $150(25.0)$ & 1.89 & $4^{\text {th }}$ \\
\hline $\begin{array}{c}\text { It needs high financial resources } \\
\text { for inputs }\end{array}$ & $128(21.3)$ & $94(15.7)$ & $117(19.4)$ & $261(43.5)$ & 1.85 & $5^{\text {th }}$ \\
\hline $\begin{array}{c}\text { It can assure the need of } \\
\text { agricultural procedures at } \\
\text { national level }\end{array}$ & $133(22.2)$ & $150(25.0)$ & $100(16.7)$ & $217(36.1)$ & 1.67 & $6^{\text {th }}$ \\
\hline $\begin{array}{c}\text { It uses natural fertilizers and } \\
\text { pesticides }\end{array}$ & $155(25.9)$ & $133(22.2)$ & $128(21.3)$ & $184(30.6)$ & 1.61 & $7^{\text {th }}$ \\
\hline $\begin{array}{c}\text { It protects the natural } \\
\text { environment }\end{array}$ & $178(29.6)$ & $83(13.9)$ & $161(26.9)$ & $178(29.6)$ & 1.56 & $7^{\text {th }}$ \\
\hline $\begin{array}{c}\text { Uses chemical fertilizers and } \\
\text { pesticides }\end{array}$ & $116(19.4)$ & $150(25.0)$ & $184(30.6)$ & $150(25.0)$ & 1.56 & $9^{\text {th }}$ \\
\hline
\end{tabular}

Table 4: Distribution of Respondents Based on Their Perception towards

Organic Production of Arable Crops

$$
n=600
$$

Grand mean $=1.86$

Source: Field Survey, 2021

\subsection{Constraints Affecting Youth Involvement in Organic Production of Arable Crops}

This section was developed with a view to investigate the degree to which selected features identified from literatures were affecting the involvement of the respondents in organic production of arable crops in the area. Results in Table 5 show that output market problem due to COVID-19 lock down (mean $=1.91$ ) ranked the highest constraints identified by the respondents followed by political and social factor (mean $=1.44)$, lack of financial support (mean $=1.32)$, shortage of bio-mass (mean $=1.28)$, inadequate supporting infrastructure (mean $=1.27)$, inability to meet the export demand (mean $=1.27$ ), high cost of inputs (mean $=1.23$ ), low production (mean $=1.22$ ), lack of appropriate agricultural policy (mean $=1.18$ ), lack of quality standard for bio-manure (mean $=1.10)$ and lack of awareness ranked the least of all the constraints. The grand mean is 0.75 which shows that there were no major constraints associated with the involvement of organic production of arable crops in the study area.

\begin{tabular}{|c|c|c|c|}
\hline Constraint & Mean & $\begin{array}{c}\text { Standard } \\
\text { Deviation }\end{array}$ & Rank \\
\hline Output market problem due to COVID-19 lock down & 1.91 & 0.83 & $1^{\text {st }}$ \\
\hline Political and social factor & 1.44 & 0.56 & $2^{\text {nd }}$ \\
\hline Lack of financial support & 1.32 & 0.69 & $3^{\text {rd }}$ \\
\hline Shortage of bio-mass & 1.28 & 0.73 & $4^{\text {th }}$ \\
\hline Inadequate supporting infrastructure & 1.27 & 0.71 & $5^{\text {th }}$ \\
\hline Inability to meet the export demand & 1.27 & 0.81 & $5^{\text {th }}$ \\
\hline High cost of inputs & 1.23 & 0.80 & $7^{\text {th }}$ \\
\hline Low production & 1.22 & 0.76 & $8^{\text {th }}$ \\
\hline Lack of appropriate agricultural policy & 1.18 & 0.73 & $9^{\text {th }}$ \\
\hline Lack of quality standard for bio-manure & 1.10 & 0.80 & $10^{\text {th }}$ \\
\hline Lack of awareness & 1.08 & 0.79 & $11^{\text {th }}$ \\
\hline
\end{tabular}

Table 5: Constraints Affecting the Involvement of Respondents in Organic Production of Arable Crops

$$
N=600
$$

Source: Field Survey, 2021

\subsection{Hypotheses Testing}

- $\mathrm{H}_{0} 1$ : There is no significant relationship between the socio-economic characteristics of the respondents and their involvement in organic production of selected arable crops.

\subsection{Results of Chi-Square Analysis}

Results of chi-square analysis in Table 6 below show that there was significant association between the level of involvement and sex $\left(\chi^{2}=22.412\right)$, marital status $\left(\chi^{2}=18.900\right)$ and cosmopoliteness $\left(\chi^{2}=41.214\right)$ of the respondents at $P$ $\leq 0.01$. However, there was no significant association between religion $\left(\chi^{2}=1.095\right)$ and the level of involvement at $p \leq$ 
0.05. This implies that the higher the level of external orientation of the respondents, the higher their involvement in organic production in the selected arable crops. Similarly, it also implies that sex can also influence the involvement of respondents in organic production the selected arable crop in the study area.

\begin{tabular}{|c|c|c|c|c|c|}
\hline Variable & $\boldsymbol{\chi}^{\mathbf{2}}$ - value & D.f & C & P-value & Decision \\
\hline Sex & $22.412^{* *}$ & 2 & 0.415 & 0.000 & $\mathrm{~S}$ \\
\hline Marital status & $18.900^{* *}$ & 4 & 0.386 & 0.001 & $\mathrm{~S}$ \\
\hline Religion & 1.097 & 2 & 0.056 & 0.579 & $\mathrm{NS}$ \\
\hline Cosmopoliteness & $14.184^{* *}$ & 2 & 0.526 & 0.000 & $\mathrm{~S}$ \\
\hline
\end{tabular}

Table6: Chi-Square Analysis Showing Association between Selected Socio-Economic Characteristics of Respondents and Level of Involvement in Organic Production of the Selected Arable Crops

**Significant at $P \leq 0.01$;

$C=$ Contingency coefficient,

D. $f=$ Degree of Freedom

Number of Respondents $=600$

$\chi^{2}=$ Chi-square

Source: Field Survey, 2021

\section{Results of Correlation Analysis}

Results in Table 7 show that household size ( $r=-0.209)$ and years of formal education $(r=-0.200)$ had significant but negative relationship with the involvement at $\mathrm{p} \leq 0.05$. This implies that increase in household size and formal education by the respondents will result to decrease in involvement in organic production of arable crops. Also, years of farming experience $(r=0.263$ ) had positive and significant relationship with the involvement of youth at $\mathrm{p} \leq 0.01$. This implies that increase in years of farming experience will enhance the involvement of the respondents in organic production of selected arable crops in the study area.

\begin{tabular}{|c|c|c|c|}
\hline Variable & r-value & p-value & Decision \\
\hline Age & -0.177 & 0.066 & NS \\
\hline Household size & $-0.209^{*}$ & 0.030 & $\mathrm{~S}$ \\
\hline Years of formal education & $-0.200^{*}$ & 0.038 & $\mathrm{~S}$ \\
\hline Years of farming experience & $0.263^{* *}$ & 0.006 & $\mathrm{~S}$ \\
\hline Income & 0.031 & 0.751 & $\mathrm{NS}$ \\
\hline
\end{tabular}

Table 7: Correlation Analysis Showing the Relationship between Some Selected Socio-Economic Characteristics and the Involvement of Respondents in Organic Production of the Selected Arable Crops

**Significant At P $\leq .01$;

NS = Not Significant;

$S=$ Significant

Number of Respondents $=600$

$R=$ Correlation Co-Efficient

$P=$ Probability Value

Source: Field Survey, 2021

\section{Conclusion}

Based on the findings of the study, the youth indicated a moderate level of involvement in organic agricultural production of the selected arable crops during COVID-19 pandemic in the study area. Therefore, it was suggested that effort should be made to provide access to credit facilities by government and non-governmental agencies so as to encourage them in organic agricultural production of arable crops during pandemic era. There should be Provision of market by the government so as to sell arable crops that are organically produced. There should be Formulation of policies that will encourage the youth to be more involved in organic agricultural production of arable crops in the study area and Nigeria at large.Adequate sensitization and creation of awareness about the health benefit of consuming organic agricultural produce.

\section{References}

i. Alliance for a Green Revolution in Africa (AGRA). 2015. Africa Agriculture Status Report: Youth in Agriculture in Sub-Saharan Africa. Nairobi, Kenya. Issue No. 3

ii. Arndt C., Chuku C., Adeniran A., Morakinyo A., Victor A., George M., Chukwuka O. (2018): International Food Policy Research Institute; Washington, DC: Nigeria's Macroeconomic Crisis Explained. NSSP Working Paper 52.

iii. FAO. Food and Agriculture Organization of the United Nations (2018); Rome, Italy: National Policy Responses to Limit the Impact of COVID-19 on Food Markets. Food Policy and Market Developments.

iv. Lamidi W. A. (2015). Impacts of Agricultural Education on Farm Mechanization in Osun State in 2003 and 2004 Farm years; Journal of General Studies in Education (JOGSE). 4 (1) 112-117.

v. Olaito (2014). Organic in agriculture, Russ Nicely, Regional Agricultural Counselor. 